\title{
Asian pear tree breeding for subtropical areas of Brazil
}

Wilson BARBosa ${ }^{a *}$, Celso Valdevino Pommer ${ }^{b}$, Antonio Fernando Caetano Tombolato ${ }^{a}$, Laura Maria Molina MeLETtI ${ }^{a}$, Renato Ferraz de Arruda VeIGA ${ }^{a}$, Mara Fernandes MourA ${ }^{b}$, Rafael PIO ${ }^{b}$

a Instituto Agronômico (IAC), Av. Theodureto de Almeida Camargo, no 1500, Bairro Vila Nova, CEP 13001-970, Campinas, SP, Brazil wbarbosa@iac.sp.gov.br

b Instituto Agronômico (IAC), Centro Avançado de Pesquisa Tecnológica do Agronegócio de Frutas, Av. Luiz Pereira dos Santos, no 1500 , Bairro Corrupira, CEP 13214-820, Jundiaí, SP, Brazil mouram@iac.sp.gov.br

${ }^{*}$ Correspondence and reprints

Fruits, 2007, vol. 62, p. 21-26 (c) 2007 Cirad/EDP Sciences All rights reserved DOI: $10.1051 /$ fruits:2006045 www.edpsciences.org/fruits

RESUMEN ESPAÑOL, p. 26

\section{Asian pear tree breeding for subtropical areas of Brazil.}

Abstract - Introduction. In São Paulo State in Brazil, there is a demand for pear tree varieties that present fruit complementary characteristics and high adaptation for a subtropical-tropical climate. Thus, our study aimed at evaluating variety selections with better fruit quality and mainly adapted to the different areas of the São Paulo State. Materials and methods. Crosses among Asian [Pyrus pyrifolia (Burm.f.) Nakai] and European (P. communis L.) pear cultivars were made in Brazil from 1992 to 1998 aiming at finding new pear types for subtropical areas of the country. The first interspecific hybrids of the IAC pear breeding program were planted in various regions of São Paulo State, at latitudes from $21^{\circ} 11^{\prime} \mathrm{S}$ to $24^{\circ} 11^{\prime} \mathrm{S}$ and (11 to 200) chilling units (CU). About 20 phenological characteristics were evaluated. The hybrids and their parents were genetically characterized through RAPD markers. Results and discussion. In the progeny of 'Okusankichi' $\times$ 'D'água', the mean age for the first bearing and fruit development period (FDP) were 3.8 years and 137 days, respectively. The fruit characters early ripening, rounded shape, russet-brown skin and crisp flesh were dominant in all crosses of Asian $\times$ Asian and Asian $\times$ European pear trees. Twenty-six hybrids were selected, of which twelve are still being tested in a subtropical-tropical climate (0-80 CU). Their main characteristics are fruit with rounded, oblate, oblong or pyriform shapes, russet-brown or green skin, and crisp or soft flesh, and plants with medium-high vigor, an upright-spreading form and a fruit development period of from (110 to 160) days. Conclusion. The precocity of hybrids is highly dependent on the parental characteristics and the environmental conditions. A fruit development period close to that of the earliest parent was obtained. In F1 generations from crossings among Asian and European pears, certain characteristics were dominant. The RAPD analysis was efficient at identifying cultivar genotypes, selections and hybrids of pear from different botanical groups.

Brazil / Pyrus communis / Pyrus pyrifolia / hybrids / tropical zones / adaptation / climatic factors / cold / pomology / RAPD

\section{Sélection de poiriers asiatiques pour les régions subtropicales du Brésil.}

Résumé - Introduction. Dans l'état de São Paulo au Brésil, il existe une demande pour des variétés de poiriers qui présenteraient des caractéristiques de fruit complémentaires et seraient bien adaptées aux climats subtropical et tropical. Notre étude a donc cherché à évaluer des variétés sélectionnées ayant une bonne qualité du fruit tout en étant spécialement bien adaptées aux différents environnements de l'état de São Paulo. Matériel et méthodes. Des croisements entre des cultivars de poiriers asiatiques [Pyrus pyrifolia (Burm.f.) Nakai ] et européens (P. communis L.) ont été effectués au Brésil de 1992 à 1998 afin de trouver de nouveaux types de poiriers pour les régions subtropicales du pays. Les premiers hybrides interspécifiques de poiriers créés par un programme d'amélioration de l'IAC ont été plantés dans diverses régions de l'État de São Paulo, situées entre les latitudes de $21^{\circ} 11^{\prime} \mathrm{S}$ à $24^{\circ} 11^{\prime} \mathrm{S}$ et présentant (11 à 200) unités de froid (UC). Environ 20 caractéristiques phénologiques ont été évaluées. Les hybrides et leurs parents ont été caractérisés génétiquement par des marqueurs RAPD. Résultats et discussion. Dans la descendance du croisement 'Okusankichi' $x$ 'D'água', l'âge moyen pour la première mise à fruits a été de 3,8 ans et la période de développement du fruit a duré 137 jours. Les caractères de précocité du fruit, forme arrondie, peau de couleur reinettebrun et chair croquante ont été dominants dans toutes les croisements de poiriers asiatique $\times$ asiatique et poiriers européen $\times$ asiatique. Vingt-six hybrides ont été sélectionnés dont douze sont toujours à l'essai en climat subtropical-tropical [(0 à 80) UC]. Ils ont principalement un fruit de forme arrondie, oblate, oblongue ou pyriforme, une peau de couleur reinette-brun ou verte, une chair croquante ou molle, et leurs plants sont de vigueur moyenne à forte, ont un port vertical et la période de développement du fruit dure (110 à 160) jours. Conclusion. La précocité des hybrides se révèle fortement dépendante des caractéristiques parentales et des conditions environnementales. La période de développement du fruit obtenue est proche de celle du parent le plus précoce. Dans la génération F1 des croisements entre poiriers asiatiques et européens, certaines caractéristiques se sont révélées dominantes. L'analyse des RAPD a été efficace pour identifier les génotypes des cultivars, les sélections et les hybrides de poiriers appartenant aux différents groupes botaniques.

Brésil / Pyrus communis / Pyrus pyrifolia / hybride / zone tropicale / adaptation / facteur climatique / froid / pomologie / RAPD 


\section{Introduction}

Pear tree cultivars are classified as European and Asian types. European pear is popularly described as being more pyriform than Asian pear, having greenish-yellow skin and melting flesh. Asian pear is usually identified as being more globose and having russetbrown skin and crisp flesh.

In Brazil, the majority of commercial cultivation is of the European type, from Pyrus communis L. species: 'Packham's' 'Triumph', 'Red Bartlett', 'Willliam's' [1, 2], 'D'água' (Water pear), 'Schmidt' and other hybrids: 'Kieffer' and 'Triunfo' [3, 4]. However, in the Southeast States, there is a tendency for a rapid increase in Asian pear cultivation [5], based on the 'Atago', 'Housui', 'Kousui', 'Nijisseiki', 'Okusankichi' [P.pyrifolia (Burm.f.) Nakai] and 'Ya Li' (P. ussurienses Max.) cultivars. In São Paulo State, the largest peargrowing areas for Asian types are mainly the President Prudente $\left[22^{\circ} 07^{\prime} \mathrm{S} ; 20\right.$ chilling units (CU)] and Sorocaba (23 30' S; $100 \mathrm{CU}$ ) regions, where 50000 plants are being cultivated [3, 6]. Of the twenty Asian pear cultivars tested, only the above cited presented relative success. In São Paulo State, there is a demand for other varietal options that present fruit complementary characteristics and high adaptation for a subtropical-tropical climate.

Thus, new studies of pear breeding were started with the aim of developing variety selections with better fruit quality and mainly adapted to the different areas of the São Paulo State. This paper presents a summary of the data obtained on crosses from Asian pears $\times$ European pears (1992-1998) and a previous description of the twelve interspecific selections being tested in a subtropical-tropical climate.

\section{Materials and methods}

From 1992 to 1998, about 14500 crosses were made involving 'Atago' $\times$ 'D'água' (IAC 193MAS and IAC 294PIN), 'Okusankichi' $\times$ 'D'água' (IAC 193GUA, 293MAS and 194PIN), 'Shinko' × 'D'água' (IAC 394), 'Okusankichi' × 'Housui' (IAC 494), 'Kousui' × 'D'água' (IAC 196), 'Nijisseiki' × 'D'água' (IAC 297), 'D'água' × 'Shinseiki' (IAC 397), 'Okusank- ichi' × 'Kousui' (IAC 498), and 'D'água' (IAC 393), 'Housui' (IAC 493), 'Taiwan Nashi-C' (IAC 593), 'Manshu Mamenashi' (IAC 693) and 'Ya Li' (IAC 793) combinations.

About 3100 seedlings were obtained. The selection process started very early, even before the first fruit set, in the greenhouse. So, 38\% of the hybrids were eliminated in initial development phases. The criteria for screening were based on modern agricultural requirements such as plant vigor and low need for special care for cultivation and chemical treatments, eliminating seedlings with symptoms of physiological anomalies and high susceptibility to diseases. These criteria ensured that fruits of good quality were selected.

'D'água', with parentage unknown, is a European type, with early ripening, yellowish-green skin, oblong-pyriform, juicy flesh, and poor keeping quality for fresh fruit. It is well adapted to a warmer climate and shows excellent blooming and fruit set. 'Taiwan Nashi-C' (P. Calleryana Decne.) and 'Manshu Mamenashi' (P. betulaefolia Bunge) are rootstock cultivars.

After extraction, the pollen was dried out, submitted to a germination test and stored in a cold, dry chamber. It was applied on stigmas with small paintbrushes. The seeds extracted from mature fruits were stratified for 40-90 days. The emergence and the initial development of seedlings were carried out under greenhouse conditions for 10 months. The hybrids were cultivated at densities from (833 to 1333 ) trees $\cdot \mathrm{ha}^{-1}$ in the five regions: Pindorama (21ำ $11^{\prime} \mathrm{S}$; $\left.11.4 \mathrm{CU}\right)$, Monte Alegre do Sul (22० 41' S; $39.6 \mathrm{CU})$, Limeira (22 33' S; 24.1 CU), Artur Nogueira $\left(22^{\circ} 34^{\prime} \mathrm{S} ; 24 \mathrm{CU}\right)$ and Guapiara (24 $11^{\prime} \mathrm{s}$; $200 \mathrm{CU})$.

About 20 phenological characteristics were evaluated: plant vigor, architecture, sanity, type and amount of buds, time and intensity of flowering and fructification; fruit format, color of the film, pulp type, flavor and aroma, maturation cycle and frigorification. The hybrids and their parents were characterized through RAPD markers. The young leaves for molecular analyses were collected from original seedlings. The DNA extraction and analysis of the results were carried out as outlined by Sawazaki et al. [4]. 


\section{Results and discussion}

We used 3137 plants originated from crossings and from open pollination. Of these, 38\% were eliminated because they presented severe symptoms of physiologic anomalies and common diseases of the culture. The elimination of hybrids, in the initial phase of development, is a very polemic action to meliorate fruitfulness; it is conjectured, because of the risks of the loss of promising material, mainly referring to the superior characteristics of the fruit. Even with such a risk, it was opted to discard the undesirable material, because the selection of cultivars highly dependent on intensive cultural and chemical treatments is not justified anymore.

In all the places of cultivation, the hybrids developed appropriately, with a medium mortality of $3.2 \%$ in relation to the total population.

\subsection{Juvenility}

The juvenile period varied from (2 to 8) years, depending on the crossing and environmental conditions. According to Li [7], in pear crosses of the P. pyrifolia (Burm.f.) Nakai species, involving early $x$ early, early $\times$ late and late $\times$ late parentages, the juvenile period was $(4.43,5.03$ and 6.05) years, respectively. In $P$. communis $\mathrm{L}$. and $P$. ussurienses Max. crosses, the juvenile period may vary from (7 to 12 ) years [8]. In our research, the average length of the juvenile period was slightly lower than that cited in the literature. For the IAC 194PIN ('Okusankichi' $\times$ 'D'água') progenies, cultivated in Pindorama, the average length of the juvenile period was 3.8 years. Hybrids from the same cross (IAC 193MAS and IAC 193GUA), when cultivated in Monte Alegre do Sul and Guapiara, presented averages of (4.2 and 5.2) years, respectively. In Pindorama, some $12 \%$ of the hybrids of progeny from IAC 193PIN bloomed in the second year of cultivation. In 8 years, about $96 \%$ of these hybrids fruited. A tendency of shortening of the juvenile period occurred in the progenies whose parents presented an early fruit development period. For open-pollinated descendants of 'Housui' and 'D'água', the average length of the juvenile period was, respectively, (3.4 and 3.5) years. Visser et al.
[9], studying thirty-three P. communis progenies, reported that the juvenile period is controlled by a quantitative genetic inheritance, with significant additive action.

\subsection{Fruit-ripening season}

The descendants of IAC 194PIN presented early maturation of fruits, inherited from the female parent 'D'água', with early maturity. 'D'água' and 'Okusankichi' fruits ripen in December-January and March-April, respectively, with an average fruit development period of (125 and 185) days, depending on the place of cultivation. In these descendants, $100 \%$ of the hybrids presented a FDP shorter than 180 days, which means that they were earlier than the male parent 'Okusankichi'. This was also verified by Crane and Lewis [10], in P. communis F1, whose descendants had been much earlier maturing than the parents had. In the progeny IAC 194 PIN, it was verified that $(52,33$ and 15$) \%$ of the hybrids presented a fruit development period inferior or equal to (130, 131-150, and 151-180) days, respectively. Statistically, the fruit development period average was 137 days.

\subsection{Fruit shape}

Pear cultivars present diversified fruit shapes. The most common are the round, oblate, ovate, oblong, conical, pyriform and long ones. In our research, it was opted to classify the pears into: globose, oblate, oblong and pyriform shapes. In the hybrid progenies, the dominance of the globose shape, a characteristic inherited from the Asian parents, was evident. In the 'Okusankichi' × 'D'água' progeny, it was verified that $(42.3,26.9,19.2$ and 11.5$) \%$ of the shapes were globose, oblong, oblate and pyriform, respectively. The dominance of the rounded over the pyriform shapes was observed by Zielinski et al. [11] in P. communis progenies. Similar results have been reported by $\mathrm{Li}$ [7], who observed $49.2 \%$ of rounded shapes when crossing oblong with round pears.

\subsection{Fruit skin color}

The Asian pears, 'Okusankichi' and 'Atago', at harvest had greenish-brown russet skin. 


\section{W. Barbosa et al.}

Table I.

Description of the major fruit characteristics of twelve new Asian pear selections tested at the Instituto Agronômico (IAC). Campinas, SP, Brazil, 2004.

\begin{tabular}{|c|c|}
\hline Selection & Description of the major fruit characteristics \\
\hline $\begin{array}{l}\text { IAC 193-18 } \\
\text { ('Atago' × 'D'água') }\end{array}$ & $\begin{array}{l}\text { Large }(250 \mathrm{~g}) \text {, globose, golden-brown russet skin and covered with small and sparse light yellow lenticels } \\
\text { (similar to IAC 293-5). } \\
\text { Flesh is white, crisp, sweet and juicy with medium sugar content ( } 13^{\circ} \text { Brix). It has excellent quality and } \\
\text { ripens in mid-March, together with 'Okusankichi'. }\end{array}$ \\
\hline $\begin{array}{l}\text { IAC 193-122 } \\
\text { ('Atago' x 'D'água') }\end{array}$ & $\begin{array}{l}\text { Medium }(190 \mathrm{~g}) \text {, globose-oblate with a light golden-brown russet skin with small lenticels. } \\
\text { Flesh is tender-crisp, white, juicy and sweet ( } 14^{\circ} \text { Brix). Ripens early March. }\end{array}$ \\
\hline $\begin{array}{l}\text { IAC 194-15 } \\
\text { ('Okusankichi' × 'D’água') }\end{array}$ & $\begin{array}{l}\text { Very large }(350 \mathrm{~g}) \text {, globose-oblong, brown russet skin with conspicuous creamy lenticels. } \\
\text { Flesh is crisp, transparent-white, juicy and sweet ( } 14^{\circ} \text { Brix) and with very few stone cells. Ripens mid- } \\
\text { January. }\end{array}$ \\
\hline $\begin{array}{l}\text { IAC 194-132 } \\
\text { ('Okusankichi' × 'D'água') }\end{array}$ & $\begin{array}{l}\text { Medium }(210 \mathrm{~g}) \text {, oblong-pyriform, golden-brown to orange-brown russet skin with small creamy lenticels. } \\
\text { Transparent-white flesh is crisp, firm, juicy and sweet-acid ( } 14{ }^{\circ} \text { Brix). One of the earliest-ripening } \\
\text { selections. Ripens in early January. }\end{array}$ \\
\hline $\begin{array}{l}\text { IAC 293-5 } \\
\text { ('Okusankichi' × 'D'água') }\end{array}$ & $\begin{array}{l}\text { The most promising selection, temporarily named Alegria (Happiness). Medium-to-large ( } 255 \mathrm{~g}) \text {, globose, } \\
\text { moderately oblate, golden-brown to orange-brown russet skin with small and sparse light yellow lenticels. } \\
\text { Crisp flesh is juicy and sweet ( } 13^{\circ} \text { Brix), excellent for fresh eating, one of the best. Ripens mid-February, } \\
140 \pm 10 \text { days after full bloom. }\end{array}$ \\
\hline $\begin{array}{l}\text { IAC 294-13 } \\
\text { ('Atago'x 'D'água') }\end{array}$ & $\begin{array}{l}\text { Medium ( } 150 \mathrm{~g}) \text {, globose-oblate, golden-brown russet skin with large and conspicuous creamy lenticels. } \\
\text { Flesh is crisp, white, firm and very juicy and sweet ( } 14^{\circ} \text { Brix). Ripens mid-April. }\end{array}$ \\
\hline $\begin{array}{l}\text { IAC 294-117 } \\
\text { ('Atago'× 'D'água') }\end{array}$ & $\begin{array}{l}\text { Medium ( } 160 \mathrm{~g}) \text {, globose-oblong (similar to 'Seleta), golden-green russet skin with very creamy lenticels. } \\
\text { Crisp flesh, transparent-white, very sweet and juicy ( } 14^{\circ} \text { Brix) and few stone cells. Ripens mid-March. }\end{array}$ \\
\hline $\begin{array}{l}\text { IAC 394-11 } \\
\text { ('Shinko'x 'D'água') }\end{array}$ & $\begin{array}{l}\text { Very large }(335 \mathrm{~g}) \text {, globose-oblong, brown russet skin with creamy lenticels. } \\
\text { Flesh is white-creamy, crisp, with few stone cells and sweet and juicy }\left(12^{\circ} \text { Brix). Ripens mid-April. }\right.\end{array}$ \\
\hline $\begin{array}{l}\text { IAC 394-14 } \\
\text { ('Shinko' x 'D’água) }\end{array}$ & $\begin{array}{l}\text { Medium ( } 180 \mathrm{~g}) \text {, globose, bronze-brown russet skin with small white creamy lenticels. } \\
\text { Flesh semi-crisp, slightly creamy, very juicy and sweet ( } 12^{\circ} \text { Brix). Ripens late-April. }\end{array}$ \\
\hline $\begin{array}{l}\text { IAC 394-115 } \\
\text { ('Shinko'x 'D'água') }\end{array}$ & $\begin{array}{l}\text { Medium ( } 155 \mathrm{~g}) \text {, globose-round, golden-brown lightly green skin with small creamy lenticels. } \\
\text { Crisp flesh, white-creamy, very juicy and sweet ( } 12^{\circ} \text { Brix), with few stone cells. Ripens mid-March. }\end{array}$ \\
\hline $\begin{array}{l}\text { IAC 394-119 } \\
\text { ('Shinko'x 'D'água') }\end{array}$ & $\begin{array}{l}\text { Large }(390 \mathrm{~g}) \text {, globose-oblong, dark-brown russet skin with large and creamy lenticels. } \\
\text { Crisp flesh, white, sweet and juicy ( } 12^{\circ} \text { Brix) and very few stone cells. It has excellent quality and ripens in } \\
\text { early January. }\end{array}$ \\
\hline $\begin{array}{l}\text { IAC 494-12 } \\
\text { ('Okusankichi' × 'Housui') }\end{array}$ & $\begin{array}{l}\text { Large }(260 \mathrm{~g}) \text {, globose-round, light golden-brown russet skin with prominent creamy lenticels, especially } \\
\text { at the calyx end. } \\
\text { Flesh is tender-crisp, transparent-creamy, very juicy, sweet }\left(12^{\circ} \text { Brix }\right) \text { and medium stone cells. Ripens late } \\
\text { February to early March. }\end{array}$ \\
\hline
\end{tabular}

Later, after maturation, these pears had skins with golden tonalities. On the other hand, European pears presented, in the majority, greenish fruits and, at harvest, turned yellowish when completely mature. The brown skin is dominant in hybrids from combinations of Asian $\times$ Asian and Asian $\times$ European pears. This also occurred in open-pollinated European and Asian pear progenies. White et al. [12] reported high heritability (0.55) for the russet trait, in Asian $\times$ Asian and Asian $\times$ European progenies. In descendants of the open-pollinated 'D'água', the majority of fruits showed greenish skin, and a recessive character [11].

\subsection{Flesh, flavor and aroma}

The Asian pears, with firm and crisp flesh characteristics, differ greatly from the European pears that are soft and melting. In IAC progenies, the crisp and gritty flesh and sweet taste showed a dominant relationship to the typical characteristics of the European pears. In the crossings of Asian $\times$ Asian pears, 
the descendants presented $100 \%$ crisp fleshes. White et al. [12] reported high heritability for crisp flesh (0.89), medium for juicy (0.21) and aromatic (0.36) and low for sweet (0.07) and astringent (0.01), in crossings involving different Asian and European pears.

\subsection{RAPD}

For genetic characterization of parents and their hybrids, clear separation was evident among the different genotypes. The obtained dendrogram was confirmed by the principal coordinate analysis and separated the genotypes into three main groups, clearly distinguishing the Asian genotypes from the occidental ones: (1) the Asian pears and their hybrids; (2) the occidental pears and the descendants of 'D'água'; (3) the rootstocks and their descendants.

These results confirm the effectiveness of RAPD methodology for cultivar identification, selections and hybrids belonging to different botanical groups [4, 13].

Twenty-six hybrids were selected, and twelve of them are still being tested in a subtropical-tropical climate $(0-80 \mathrm{CU})$. These hybrids are IAC 193-18, IAC 193-122, IAC 194-15, IAC 194-132, IAC 293-5, IAC 294-13, IAC 294-117, IAC 394-11, IAC 394-14, IAC 394115, IAC 394-119 and IAC 494-12 (table I).

\section{Conclusions}

(1) The hybrids from 'Okusankichi' $\times$ 'D'água' had an average juvenile period of (3.8 and 5.2) years in warmer and colder regions, respectively. The precocity of hybrids is highly dependent on the parental characteristics and the environmental conditions.

(2) In crosses involving pears of different maturing periods, fruit development period means closer to the earliest parent were obtained.

(3) In F1 generations from crossings among Asian and European pears, dominance of the globose shape, russet-brown skin, crisp, gritty and sweet flesh, and light aroma were observed.

(4) RAPD analysis is efficient at identifying cultivar genotypes, selections and hybrids of pear from different botanical groups.

\section{Acknowledgements}

The authors thank Katsuyoshi Murata (Rancharia), Jorge Suzuki (Narandiba), Mitsuo Myasaki (Ibiúna), Joaquim A.M. Franco (Avaré), Antonio Lucio M. Martins (Pindorama), Joaquim Adelino de Azevedo Filho (Monte Alegre do Sul), Jairo Lopes de Castro (Capão Bonito), Marcilene de Moraes and Antonio Carlos de Carvalho for technical support. This research was supported by grants from the National Council for Scientific and Technological Development (CNPq).

\section{References}

[1] Bell R.L., Pear genetics and germplasm priorities for breeding, Acta Hortic. 124 (1982) 13-20.

[2] Ribeiro P.A., Brighenti E., Bernardi J., Comportamento de algumas cultivares de pereira Pyrus communis L. e suas características nas condições do Planalto Catarinense, Empasc, Bol. téc. 56, Florianópolis, Brasil, 1991, $53 \mathrm{p}$

[3] Barbosa W., Pommer C.V., Ribeiro M.D., Veiga R.F.A., Costa A.A., Distribuição geográfica e diversidade varietal de frutíferas e nozes de clima temperado no Estado de São Paulo, Rev. Bras. Frutic. 25 (2) (2003) $341-$ 344.

[4] Sawazaki H.E., Barbosa W., Colombo C.A., Caracterização e identificação de cultivares e seleções de pereiras através de marcadores RAPD, Rev. Bras. Frutic. 24 (2) (2002) 447-452.

[5] Faoro I.D., Nakasu B.H., Japanese pear growing in Brazil, Acta Hortic. 567 (2002) 97105.

[6] Pedro Junior M.J., Ortolani A.A., Rigitano O., Alfonsi R.R., Pinto H.S., Brunini O., Estimativa de horas de frio abaixo de 7 e $13^{\circ} \mathrm{C}$ para regionalização da fruticultura de clima 
temperado no Estado de São Paulo, Bragantia 38 (1979) 123-130.

[7] Li Z.L., Advances of pear breeding program at Zhejiang Agricultural University, Acta Hortic. 279 (1990) 167-184.

[8] Visser T., Juvenile phase and growth of apple and pear seedlings, Euphytica 13 (1964) 119-129.

[9] Visser T., Verhaegh J.J., De Vries D.P., A comparison of apple and pear seedlings with reference to the juvenile period. I. Seedling growth and yield, Euphytica 25 (1976) 343351.
[10] Crane M.B., Lewis D., Genetical studies in pears: vegetative and fruit characters, Heredity 3 (1949) 85-97.

[11] Zielinski Q.B., Reimer F.C., Quackenbush V.L., Breeding behavior of fruit characteristics in pears, Pyrus communis L, in: Proc. Am. Soc. Hortic. Sci. 86 (1965) 81-87.

[12] White A.G., Brewer L.R., Alspach P.A., Heritability of fruit characteristics in pear, Acta Hortic. 538 (2000) 331-338.

[13] Oliveira C.M., Mota M., Monte-Corvo L., Goulão A., Silva D.M., Molecular typing of Pyrus based on RAPD markers, Sci. Hortic. 79 (1999) 63-174.

\section{Selección de Pera asiática para las áreas subtropicales de Brasil.}

Resumen - Introducción. En el Estado de São Paulo, Brasil hay una demanda por variedades de peras que presenten características complementarias y alta adaptación a climas de tipo subtropical-tropical. De esta forma, este trabajo tuvo por objetivo evaluar selecciones de variedades con mejor calidad de fruta y principalmente observar cual de ellas se adaptaría mejor en las diferentes regiones del Estado de São Paulo. Material y métodos. Cruces entre cultivares de pera asiática [P. pyrifolia (Burm.f.) Nakai] y pera europea (P. communis L.) fueron realizados de 1992 a 1998 con la finalidad de encontrar un nuevo tipo de pera que se adaptara mejor en las regiones subtropicales de Brasil. El primer híbrido interespecífico de pera criado por el IAC fue plantado en varias regiones del Estado de São Paulo, entre las latitudes $21^{\circ} 11^{\prime} \mathrm{S}$ y $24^{\circ} 11^{\prime} \mathrm{S}$ y horas frío (HF) entre 11 y 200. Fueron caracterizados geneticamente, por medio de marcadores RAPD, el híbrido y sus parentales. Resultados y discusión. En la descendencia de 'Okusankichi' $\times$ 'D'água', la edad promedia para la primera producción y el periodo de desarrollo de fruta (PDF) fueron 3.8 años y 137 días, respectivamente. Los caracteres de fruta madurez precoz, forma redondeada, cáscara café-rojiza y pulpa crocante fueron dominantes en todos los cruces de pera asiática $\times$ asiática y asiática $\times$ europea. Fueron seleccionados veinte y seis híbridos de los cuales 12 todavía están bajo estudio en clima subtropical-tropical (0-80 HF). Sus principales características son frutas redondas, oblicuas o periformes, cáscara café-rojiza, pulpa crocante o carnosa, planta con vigor medio a alto, forma vertical extendida y PDF entre 110 y 160 días. Conclusión. La precocidad de los híbridos es altamente dependiente de las características parentales y de las condiciones ambientales. El período del desarrollo de la fruta de los híbridos es más corto en comparación al de los parentales. En la generación F1 de los cruces entre perales asiáticos y europeos, algunas características se revelaron dominantes. El análisis de los RAPD fue eficaz para definir genotipos de cultivar, selecciones e híbridos de perales que pertenecían a los distintos grupos botánicos.

Brasil / Pyrus communis / Pyrus pyrifolia / híbridos / zona tropical / adaptación / factores climáticos / frio / pomología / RAPD 